\title{
Peningkatan Hasil Belajar Siswa Kelas X IPS 1 dalam Pembelajaran Seni Tari Melalui Metode Jigsaw di SMA Negeri 1 Kerinci Tahun Pelajaran 2019/2020
}

\author{
Ning Ayuni \\ SMA Negeri 1 Kerinci \\ Correspondence email: ningayuni23506@gmail.com
}

\begin{abstract}
Abstrak. Jenis penelitian ini adalah penelitian tindakan kelas (PTK).Penelitian ini bertujuan meningkatkan prestasi siswa kelas X IPS 1 dalam pembelajaran seni tari melalui metode jigsaw di SMA Negeri 1 Kerinci. Subjek penelitian ini adalah siswa kelas X IPS 1 SMAN 1 Kerinci berjumlah 20 siswa. Setting penelitian berlangsung di SMA Negeri 1 Kerinci yang terletak di Jalan Hiang Lestari kecamatan Sitinjau Laut Kabupaten Kerinci. Prosedur penelitian ini terdiri dari 2 siklus, setiap siklus terdiri dari empat pertemuan dengan langkah-langkah: (1) perencanaan, (2) implementasi tindakan, (3) observasi, (4) refleksi. Teknik pengumpulan data yang digunakan adalah observasi, tes penampilan, dokumentasi, wawancara, dan angket. Sedangkan instrumen yang digunakan adalah catatan lapangan, lembar observasi, lembar penilaian, pedoman wawancara, dan angket kuesioner. Hasil penelitian menunjukkan bahwa aktivitas positif siswa dalam pembelajaran selama dua siklus mengalami peningkatan. Hal tersebut menunjukkan bahwa tingkat keaktifan siswa selama pembelajaran mengalami kenaikan. Hal tersebut ditandai dengan antusias siswa dengan baik dan kerja kelompok yang kompak, siswa kreatif dalam membuat gerak tari dan pola lantai, siswa mampu menggabungkan gerak tari menjadi sebuah karya, serta percaya diri waktu mempresentasikan gerak tari dan pola lantai yang mereka buat. Peningkatan prestasi didukung oleh data kuantitatif bahwa yang mendapatkan nilai lebih dari 75 atau tuntas sebelum tindakan sebesar 25\% sebanyak 5 siswa. Setelah metode jigsaw dilaksanakan dalam pembelajaran seni tari siswa kelas X IPS 1 SMAN 1 Kerinci, pada akhir siklus I persentase siswa yang tuntas menjadi $60 \%$ sebanyak 12 siswa dan siswa yang belum tuntas menjadi $40 \%$ sebanyak 8 siswa. Selanjutnya pada akhir siklus II persentase siswa yang tuntas menjadi $85 \%$ sebanyak 17 siswa dan siswa yang belum tuntas menjadi 15\% sebanyak 3 siswa. Dengan demikian dapat disimpulkan bahwa metode jigsaw dapat meningkatkan prestasi siswa dalam pembelajaran seni tari.
\end{abstract}

Kata kunci: prestasi siswa; pembelajaran; metode Jigsaw

Abstract. This research was a classroom action research. The research objective was to improve the student's achievement on Dancing Art subject by using Jigsaw method. The research participant was the students at grade X IPS 1 SMAN 1 Kerinci consisted of 20 students. The research was done in two cycles which had four phases (1) Planning (2) Action (3) Observation (4) Reflection. The data were collected by using observation, performance test, documentation, interview and questionnaire. The instruments of the research were field note, observation sheet, research sheet, interview guide, and Questionnaire. The analysis result showed that the student's learning activeness during the two cycles improved. It could be seen from the improvement of the student's activeness level. It was observed from their well enthusiastic and cooperative team work in forming dancing moves and floor pattern, the students were able to gather the dancing moves into a dancing creation, and they were performing both things confidently. The improvement in achievement was seen from the quantitative data that there were 5 students (25\%) who got 75 in pre-cycle. It went better when Jigsaw method was implementd in cycle 1 and 2. There were 12 students (60\%) who got achieved score, and 8 of them (40\%) who got unachieved score in the first cycle. Then, the next cycle showed that there were 17 students (85\%) who got achieived score and 3 of them (15\%) who were at unachieved level. It concluded that Jigsaw method improved the student's achievement in Dancing Art Subject.

Keywords: student achievement; learning; methods Jigsaw

\section{PENDAHULUAN}

Pendidikan merupakan kebutuhan dasar manusia yang bertujuan untuk membentuk kepribadian, sikap, dan tingkahlaku serta nilai budaya yang strategis guna menjunjung tinggi harkat dan martabat manusia.

Pendidikan seni pada hakikatnya merupakan proses pembentukan manusia melalui seni. Pendidikan secara umum berfungsi untuk mengembangkan kemampuan setiap anak (Peserta didik) menemukan pemenuhan dirinya (personal fulfillment) dalam hidup, untuk mentransmisikan warisan budaya, memperluas kesadaran sosial dan sebagai jalan untuk menambah pengetahuan. (Tim Pengembangan Ilmu Pendidikan
UPI: 2007) mengemukakan tujuan dasar pendidikan seni untuk membentuk kepekaan sejak pertama kali mereka mengalaminya sebagai bentuk dasar dari ekspresi dan sebagai tanggapan dalam kehidupan.

Program seni di sekolah memfasilitasi anak-anak menyediakan peluang untuk pemenuhan dirinya melalui pengalaman seni berdasarkan sesuatu yang dekat dengan kehidupan dan dunianya. Ruang lingkup pendidikan seni di sekolah meliputi pencapaian artistik yang mengakspresikan dan mengkomunikasikan segala hal yang berkaitan dengan kebutuhan untuk menjadi manusia melalui seni ( seni rupa, musik, tari, dan drama). 
Melalui pendidikan seni, siswa dilatih untuk mengembangkan bakat kreatif, kemampuan dan keterampilan yang dapat ditransfer pada kehidupan kerja sebagai mata pencaharian maupun untuk rekreasi sebagai hobby atau kesenangan.

Berdasarkan ulasan yang telah dijabarkan di atas maka sangatlah penting bagi para pendidik, khususnya guru, memahami karakteristik materi, peserta didik, dan metodologi pembelajaran dalam proses pembelajaran, terutama berkaitan dengan metode-metode pembelajaran modern. Dengan segala keterbatasan yang ada, peneliti mencoba membantu untuk memaksimalkan proses belajar peserta didik melalui penggunaan metode pembelajaran modern yaitu metode pembelajaran jigsaw.

Menurut Isjoni (2013), metode jigsaw adalah metode yang mengharuskan semua siswa untuk aktif ketika sedang berkelompok. Metode pembelajaran ini didesain untuk meningkatkan rasa tanggung jawab siswa terhadap pembelajarannya sendiri dan juga pembelajaran orang lain.

Di dalam metode pembelajaran ini, siswa tidak hanya mempelajari materi yang diberikan, tetapi mereka juga harus siap memberikan materi tersebut kepada kelompoknya. Sehingga baik kemampuan secara kognitif maupun sosial, siswa dapat berkembang. Pembelajaran ini lebih meningkatkan kerjasama antar siswa. Penggunaan metode pembelajaran jigsaw ini diharapkan proses pembelajaran akan lebih variatif, inovatif, dan konstruktif dalam merekonstruksi wawasan pengetahuan dan implementasinya, sehingga dapat meningkatkan aktivitas, kreativitas, dan hasil belajar peserta didik.

Berdasarkan hasil pengamatan yang dilakukan pada saat observasi di kelas, hasil pembelajaran seni tari pada siswa kelas $X$ IPS 1 SMA Negeri 1 Kerinci terlihat kurang memuaskan. Pemahaman siswa terhadap materi yang diberikan oleh guru masih rendah, siswa masih bersifat pasif dan cenderung hanya melakukan apa yang diperintahkan guru. Berdasarkan hasil evaluasi tes tertulis yang pernah dilaksanakan sebelum dilakukan tindakan pada saat pembelajaran seni tari di kelas X IPS 1, dari 20 orang siswa, hanya 5 orang siswa yang mendapatkan nilai di atas KKM, sedangkan 15 siswa mendapatkan nilai di bawah KKM sedangkan pada hasil tes praktik seni tari masih banyak siswa yang pasif dan enggan untuk mempraktikkannya.

Prestasi merupakan hasil belajar yang terjadi setelah proses belajar mengajar selesai. Prestasi sama halnya dengan hasil belajar. Prestasi belajar dapat dilihat dari penguasaan siswa terhadap mata pelajaran yang ditempuh.

Menurut Chatarina (2006), hasil belajar merupakan perubahan perilaku yang diperoleh pembelajar setelah mengalami aktivitas belajar. Hasil belajar berwujud angka ataupun pernyataan yang mencerminkan tingkat penguasaan materi pelajaran bagi para siswa, yang lebih dikenal dengan prestasi belajar. Belajar meliputi tidak hanya mata pelajaran, tetapi juga penguasaan, kebiasaan, persepsi, kesenangan, minat, penyesuaian soal, bermacam-macam keterampilan, dan cita-cita. Dalam bidang seni tari dilakukan tes perbuatan, siswa ditugasi untuk melakukan perbuatan atau tindakan tertentu seperti tes keterampilan menari.

Pembelajaran seni tari merupakan pembelajaran yang dilakukan oleh pendidik untuk menyampaikan ilmu-ilmu tentang seni tari, mengekspresikan jiwa manusia dengan berbagai metode sehingga dapat melakukan kegiatan belajar. H'Doubler dalam Soedarsono (1996) di jelaskan Tari adalah ekspresi gerak ritmis dari keadaan-keadaan perasaan yang secara estetis dinilai, yang lambang-lambang geraknya dengan sadar dirancang untuk kenikmatan serta kepuasan dari pengalaman-ulang, ungkapan, berkomunikasi, melaksanakan, serta dari penciptaan bentuk- bentuk. Pembelajaran melalui seni tari memfokuskan pada kemampuan siswa yang menggunakan tarian sebagai suatu alat estetika, memahami struktur gestur dan gerak untuk menangkap dan menyampaikan gagasan, pencitraan dan perasaan, tubuh digunakan sebagai bentuk ekspresi dan media komunikasi.

Metode jigsaw adalah metode yang mengharuskan semua siswa untuk aktif ketika sedang berkelompok. Metode pembelajaran ini didesain untuk meningkatkan rasa tanggung jawab siswa terhadap pembelajarannya sendiri dan juga pembelajaran orang lain. Di dalam metode pembelajaran ini siswa tidak hanya mempelajari materi yang diberikan, tetapi mereka juga harus siap memberikan materi tersebut kepada kelompoknya. Sehingga baik kemampuan secara kognitif maupun sosial siswa dapat berkembang.

Pembelajaran ini lebih meningkatkan kerjasama antar siswa (Isjoni, 2013). Penggunaan metode jigsaw ini diharapkan proses pembelajaran akan lebih variatif, inovatif, dan konstruktif dalam merekonstruksi wawasan pengetahuan dan implementasinya sehingga dapat meningkatkan aktivitas, kreativitas, dan hasil belajar peserta didik.

Menurut Trianto (2009), langkah-langkah pembelajaran jigsaw yaitu :

\section{Langkah-langkah Pembelajaran Jigsaw}

1. Siswa dibagi atas beberapa kelompok (tiap kelompok anggotanya 5 orang)

2. Materi pelajaran diberikan kepada siswa dalam bentuk teks yang telah dibagi-bagi menjadi beberapa sub bab.

3. Setiap anggota kelompok membaca sub bab yang ditugaskan dan bertanggung jawab untuk mempelajarinya. Misalnya, jika materi yang disampaikan mengenai unsur-unsur seni tari. Maka seorang siswa dari satu kelompok mempelajari tentang gerak, siswa yang lain dari kelompok satunya mempelajari tentang desain lantai, begitu pun siswa lainnya mempelajari tentang desain atas, dan lainnya lagi mempelajari tentang iringan. 
4. Anggota dari kelompok lain yang telah mempelajari sub bab yang sama bertemu dalam kelompokkelompok ahli untuk mendiskusikannya.

5. Setiap anggota kelompok ahli setelah kembali ke kelompoknya bertugas mengajar teman-temannya

Pada pertemuan dan diskusi kelompok asal, siswa-siswa dikenai tagihan berupa kuis/ujian individu.

Sumber data: Trianto. 2009. Mendesain Model Pembelajaran Inovatif-Progresif. Jakarta: Kencana Prenada Media Group.

\section{METODE}

\section{Jenis Penelitian}

Jenis penelitian yang digunakan merupakan classroom action research atau penelitian tindakan kelas (PTK). Menurut (Suyadi, 2010) Penelitian tindakan kelas adalah pencermatan dalam bentuk tindakan terhadap kegiatan belajar yang sengaja dimunculkan dan terjadi dalam sebuah kelas secara bersamaan.

\section{Subjek Penelitian}

Subjek dalam penelitian ini adalah siswa kelas $\mathrm{X}$ IPS 1 SMA Negeri 1 Kerinci Tahun Pelajaran 2019/2020 yang berjumlah 21 siswa.

\section{Setting Penelitian}

Penelitian ini dilaksanakan di SMA Negeri 1 Kerinci yang beralamat di desa hiang lestari. Waktu penelitian dilaksanakan pada bulan Agustus - November 2019.

\section{Teknik dan Instrumen Pengumpulan Data}

Teknik pengumpulan data yaitu : Tes, Pengamatan observasi, Dokumentasi.

Instrumen penelitian Lembar observasi, Lembar penilaian, kuesioner, Pedoman wawancara

\section{Teknik Analisis Data}

Teknik analisis data kualitatif

Data kualitatif dianalisis secara deskriptif kualitatif yaitu mendeskripsikan kemampuan siswa dalam proses pembelajaran seni tari dengan metode jigsaw sebelum dan sesudah implementasi tindakan, hasil observasi lapangan, wawancara dengan sesama guru tari, dan dokumentasi. Data kualitatif berupa peningkatan, pengetahuan, dan pengalaman siswa dalam proses pembelajaran seni tari dianalisis dengan teknik deskriptif kualitiatif

\section{Teknik analisis data kuantitatif}

Data kuantitatif yaitu informasi yang muncul di lapangan dan memiliki karakteristik yang dapat ditampilkan dalam bentuk angka, berupa hasil tes siswa diakhir setiap siklus dalam penelitian tindakan kelas ini dianalisis dengan teknik analisis deskriptif kuantitatif sederhana. Data kuantitatif berupa tes keterampilan menari, digunakan untuk memperkuat hasil data kualitatif.

\section{Tindakan yang dilakukan}

Tindakan dalam penelitian ini akan dilakukan dalam 2 siklus. Adapun langkah-langkahnya adalah :

\section{Siklus I}

a. Perencanaan

1) Mengidentifikasi masalah melalui : Tes kemampuan siswa, Aktivitas siswa, Penilaian

2) Mendeskripsikan alternatif tindakan yang akan dilakukan.

3) Menyiapkan rancangan pembelajaran, seperti materi dan metode pembelajaran.

4) Merencanakan waktu pelaksanaan penelitian, yang direncanakan mulai Agustus- November 2019

b. Implentasi Tindakan

Pelaksanaan tindakan dalam penelitian ini didasarkan pada perencanaan yang telah disusun, yaitu menerapkan metode pembelajaran jigsaw untuk meningkatkan prestasi belajar seni tari siswa.

c. Observasi

Observasi yang dilakukan adalah proses pengamatan terhadap pelaksanaan pembelajaran Seni Budaya dengan menggunakan metode pembelajaran Jigsaw Observasi ini dilakukan pada saat proses pembelajaran dimulai dengan menggunakan lembaran observasi guru dan siswa untuk mengamati kegiatan guru dan siswa selama proses pembelajaran berlangsung. Pemberian soal postest dilaksanakan setiap akhir siklus untuk mengetahui peningkatan hasil belajar seni budaya yang dicapai siswa.

\section{d. Refleksi}

Pada tahap refleksi ini, siswa yang masih mempunyai kekurangan dalam melakukan gerak, diantaranya kurang percaya diri saat presentasi, belum hafal, belum ada penjiwaan, menjadi maksimal dalam melakukan praktik gerak dengan baik. serta antar satu teman dengan teman lainnya dapat berkerjasama, berdiskusi dan bertanggung jawab dengan kelompoknya.

\section{Siklus II}

a. Perencanaan

1) Mengidentifikasi masalah melalui hasil observasi atau pengamatan siklus I, angket penelitian, aktivitas siswa dan penilaian

2) Mendiskusikan alternatif tindakan yang akan dilakukan sebagai perbaikan dari siklus I.

3) Menyiapkan rancangan pembelajaran.

4) Merencanakan waktu pelaksanaan penelitian, yang direncanakan mulai Agustus November 2019.

a. Implentasi Tindakan

Pelaksanaan tindakan dalam penelitian ini didasarkan pada perencanaan yang telah disusun, yaitu 
menerapkan metode pembelajaran jigsaw untuk meningkatkan prestasi belajar seni tari siswa.

b. Observasi

Observasi yang dilakukan adalah proses pengamatan terhadap pelaksanaan pembelajaran Seni budaya dengan menggunakan metode pembelajaran Jigsaw . Observasi ini dilakukan pada saat proses pembelajaran dimulai dengan menggunakan lembaran observasi guru dan siswa untuk mengamati kegiatan guru dan siswa selama proses pembelajaran berlangsung.

c. Refleksi

Setelah data dikumpulkan pada siklus I, data tersebut dianalisis oleh guru bersama kolaborator, kelemahankelemahan yang terjadi pada siklus I ditetapkan tindakannya untuk mengatasi kekurangan pada siklus berikutnya. Tujuan yang dicapai pada pelaksanaan tiap siklus adalah hasil belajar Seni budaya siswa mencapai KKM dan target yang diharapkan dalam penelitian, baik secara individual maupun klasikal.

\section{Desain/Prosedur Penelitian \\ Perencanaan Tindakan}

Kegiatan yang dilakukan dalam perencanaan tindakan meliputi :
a. Menyusun
RPP
(Rencana
Pelaksanaan
Pembelajaran).
b. Menyusun instrumen penelitian (lembar observasi, pedoman wawancara, angket).
c. Menyusun perangkat pembelajaran (materi pembelajaran).

\section{Pelaksanaan Tindakan}

Pelaksanaan adalah menerapkan apa yang telah direncanakan dalam perencanaan. Hasil dari pelaksanaan tindakan berupa aktivitas- aktivitas guru dan siswa. Aktivitas yang ditulis misalnya : bagaimana cara guru mengawali, kolaborator melaksanakan dan mengevaluasi tindakan selama proses pembelajaran dan bagaimana cara guru mengamati perilaku siswa untuk memperoleh data penelitian.

\section{Observasi}

Pengumpulan data PTK dilakukan dengan observasi kelas untuk melihat kualitas hasil belajar sesuai dengan indikator yang telah ditetapkan. Misalnya : aktivitas belajar, interaksi siswa, hasil belajar, dll.

\section{Refleksi}

Refleksi merupakan pengkajian terhadap keberhasilan dan kegagalan dalam mencapai tujuan sementara, dan untuk menentukan tindak lanjut dalam rangka mencapai tujuan akhir. Dalam tahap refleksi, keputusan perlu didiskusikan dengan seluruh personal yang terlibat dalam penelitian. Rencana tindak lanjut diputuskan jika hasil dari siklus pertama belum memuaskan dan berdasarkan refleksi ditemukan hal-hal yang masih dapat dibenahi atau ditingkatkan.

\section{Validitas dan Reliabilitas Penelitian}

Validitas digunakan untuk mencapai keabsahan data diterapkan kriteria validitas Burs dalam Acep Yoni (2010) yang mengemukakan kriteria validitas yang dipandang paling tepat untuk diterapkan pada penelitian tindakan. Validitas yang digunakan dalam penelitian ini adalah validitas proses, validitas hasil dan validitas demokratik.

Sedangkan reliabilitas mengandung ide pokok sejauh mana hasil suatu pengukuran dengan dipercaya. Tingkat reliabilitas data dalam penelitian ini menggunakan teknik triangulasi dengan cara memanfaatkan sumber. Menurut Acep Yoni (2010), bahwa triangulasi dilakukan dengan membandingkan data hasil pengamatan dengan hasil data hasil wawancara dengan siswa, dan dengan membandingkan segala sesuatu yang dilakukan oleh siswa dengan segala sesuatu yang dikatakan peneliti.

\section{Kriteria Keberhasilan Tindakan} adalah :

Kriteria keberhasilan tindakan pada penelitian ini

1. Aktivitas belajar meningkat pada aspek yaitu (a).Partisipasi keaktifan siswa dalam kerja kelompok (b). Tanggung jawab dan kerjasama di dalam kelompok (c). Percaya diri dalam bertanya kepada guru dan tampil menari

2. Hasil belajar meningkat pada aspek (a). Ketepatan gerak dengan irama (b). Penjiwaan dan ekspresi wajah dalam menari (c). Hafalan dan penguasaan materi (d). Penguasaan teknik gerak

\section{HASIL DAN PEMBAHASAN Pra Siklus}

Pembelajaran seni budaya SMA N 1 Kerinci kelas X IPS 1 pada kondisi awal sebelum diadakannya tindakan hasil belajarnya masih rendah. Hal ini dapat dibuktikan dari studi awal bahwa dari 20 orang siswa baru 5 orang siswa atau hanya $25 \%$ yang mencapai ketuntasan belajar dengan rata-rata capaian secara klasikal 64.

\section{Siklus I}

Pada tahap ini peneliti dan kolaborator mengamati kegiatan siswa selama pembelajaran berlangsung. Peneliti mengobservasi siswa waktu proses pembelajaran dengan mengarahkan siswa yang kurang maksimal dalam melakukan gerakan.

Dari 20 siswa kelas X IPS1, yang telah memenuhi syarat ketuntasan belajar pada siklus I sejumlah 12 siswa atau sebesar $60 \%$. Sedangkan jumlah siswa yang belum tuntas sejumlah 8 siswa atau sebesar $40 \%$. Pada hasil penerapan model pembelajaran Jigsaw secara berkelompok siswa yang memperoleh nilai 55 sampai 64 tidak ada. Siswa yang memperoleh nilai 65 sampai 
dengan 74 sebanyak 8 siswa atau 40\%. Siswa yang mendapatkan nilai 75 sampai dengan 84 sebanyak 12 siswa atau $60 \%$. Sedang siswa yang mendapatkan nilai 85 sampai 100 tidak ada. Nilai rata-rata ketuntasan secara klasikal yang dicapai hanya mencapai 74 .

Tabel 1. Persentase hasil belajar siswa siklus I

\begin{tabular}{cccc}
\hline No & Skor & Jumlah Siswa & Persentase \\
\hline 1 & Skor 55-64 & 0 & $0 \%$ \\
2 & Skor 65-74 & 8 & $40 \%$ \\
3 & Skor 75-84 & 12 & $60 \%$ \\
4 & Skor 85-100 & 0 & $0 \%$ \\
& Jumlah & $\mathbf{2 0}$ & $\mathbf{1 0 0 \%}$ \\
\hline
\end{tabular}

Sumber data: Pengolahan data hasil belajar seni tari siswa siklus 1

Setiap akhir siklus dilakukan evaluasi oleh peneliti dan kolaborator terkait kegiatan pembelajaran yang dilaksanakan. Kemudian dilanjutkan refleksi untuk memperbaiki kekurangan yang terjadi selama proses pembelajaran, diantaranya siswa belum hafal gerakan, siswa belum tepat dengan iringan musik. Pada tahap evaluasi atau refleksi ini peneliti dan kolaborator membetulkan gerakan siswa yang masih salah, memberi pemahaman tentang ketepatan gerakan dengan iringan musik. Hasil diskusi peneliti dan guru, digunakan untuk mencari alternatif guna memperbaiki proses pembelajaran berikutnya.

\section{Observasi}

Peningkatan juga dapat dilihat dari aktivitas siswa yang lebih baik dari pada sebelumnya dilakukan tindakan. Siswa lebih bertanggungjawab terhadap tugas yang diberikan (60\%), kerjasama antar teman kelompok terjalin dengan baik (75\%). Siswa lebih aktif dan percaya diri bertanya kepada guru mengenai kesulitan yang dihadapinya $(65 \%)$ dan keseriusan siswa dalam menjiwai tarian (60\%). Berdasarkan hasil pengamatan ini perlu dilakukan tindakan pada siklus II.

Tabel 2. Persentase hasil observasi aktivitas belajar siswa siklus I

\begin{tabular}{clcc}
\hline No & \multicolumn{1}{c}{ Indikator Pengamatan } & $\begin{array}{c}\text { Jumlah } \\
\text { siswa }\end{array}$ & $\begin{array}{c}\text { Persentase } \\
(\%)\end{array}$ \\
\hline 1. & $\begin{array}{l}\text { Bertanggungjawab } \\
\text { terhadap tugas yang } \\
\text { diberikan }\end{array}$ & 12 orang & $60 \%$ \\
2. & $\begin{array}{l}\text { Kerjasama antar teman } \\
\text { kelompok terjalin dengan } \\
\text { baik }\end{array}$ & 15 orang & $75 \%$ \\
3. & $\begin{array}{l}\text { Siswa lebih aktif dan } \\
\text { percaya diri bertanya } \\
\text { kepada guru mengenai } \\
\text { kesulitan yang dihadapi }\end{array}$ & 13 orang & $65 \%$ \\
Keseriusan siswa dalam \\
menjiwai tarian
\end{tabular}

Sumber data: Pengolahan data hasil observasi aktivitas belajar seni tari siswa siklus 1

\section{Refleksi}

Pada tahap refleksi ini, siswa yang masih mempunyai kekurangan dalam melakukan gerak, diantaranya kurang percaya diri saat presentasi, belum hafal, belum ada penjiwaan, pada siklus I, mengalami peningkatan dalam melakukan praktik gerak dengan baik. serta antar satu anggota kelompok dengan teman lainnya dapat berkerjasama, berdiskusi dan bertanggung jawab dengan kelompoknya.

\section{Siklus II}

Pada akhir siklus II yaitu dilakukan pengambilan data pemahaman siswa terhadap materi yang telah diberikan melalui tes. Dari 20 siswa kelas X IPS 1 yang dinyatakan lulus atau telah memenuhi syarat ketuntasan belajar sejumlah 17 orang siswa atau sebesar $85 \%$. Sedangkan jumlah siswa yang belum tuntas sejumlah 3 siswa atau sebesar $15 \%$.

Pada siklus II, hasil penerapan model pembelajaran Jigsaw secara berkelompok siswa yang memperoleh nilai 55 sampai 64 tidak ada. Siswa yang memperoleh nilai 65 sampai dengan 74 sebanyak 3 siswa atau $15 \%$. Siswa yang mendapatkan nilai 75 sampai dengan 84 sebanyak 9 siswa atau 45\%. Sedang siswa yang mendapatkan nilai 85 sampai 1008 orang atau $40 \%$. Nilai rata-rata ketuntasan secara klasikal mencapai 85 .

Tabel 3. Persentase Hasil Belajar Siswa Siklus II

\begin{tabular}{cccc}
\hline No & Skor & Jumlah Siswa & Persentase \\
\hline 1 & $55-64$ & 0 & $0 \%$ \\
2 & $65-74$ & 3 & $15 \%$ \\
3 & $75-84$ & 9 & $45 \%$ \\
4 & $85-100$ & 8 & $40 \%$ \\
& Jumlah & $\mathbf{2 0}$ & $\mathbf{1 0 0 \%}$ \\
\hline
\end{tabular}

Sumber data: Pengolahan data hasil belajar seni tari siswa siklus 1I

Pada tahap refleksi ini, ada tiga orang siswa yang belum memenuhi kriteri ketuntasan Siswa yang belum tuntas disebabkan karena kurangnya usaha siswa untuk mendapatkan hasil yang lebih baik serta dipengaruhi dari kurangnya minat siswa terhadap pelajaran seni tari, siswa masih mempunyai kekurangan dalam melakukan gerak, diantaranya kurang percaya diri saat presentasi, belum hafal gerakan, belum ada penjiwaan, menjadi maksimal dalam melakukan praktik gerak dengan baik. serta antar satu teman dengan teman lainnya dapat berkerjasama, berdiskusi dan bertanggung jawab dengan kelompoknya.

\section{Observasi}

Berdasarkan hasil observasi dapat diketahui bahwa setelah diterapkan model pembelajaran dengan pendekatan jigsaw), keaktifan siswa menunjukkan indiktor keseriusan siswa dalam mengikuti pelajaran .

Peningkatan juga dapat dilihat dari aktivitas siswa 
Ning Ayuni, Peningkatan Hasil Belajar Siswa Kelas X IPS 1 dalam Pembelajaran Seni Tari Melalui Metode Jigsaw di SMA Negeri 1 Kerinci Tahun Pelajaran 2019/2020

yang lebih baik dari pada sebelumnya. Siswa lebih bertanggungjawab terhadap tugas yang diberikan (85\%), kerjasama antar teman kelompok terjalin dengan baik (90\%). Siswa lebih aktif dan percaya diri bertanya kepada guru mengenai kesulitan yang dihadapinya $(85 \%)$ dan keseriusan siswa dalam menjiwai tarian $(90$ $\%)$.

Tabel 4. Persentase hasil observasi aktivitas belajar siswa siklus II

\begin{tabular}{|c|c|c|c|}
\hline No & Indikator Pengamatan & $\begin{array}{c}\text { Jumlah } \\
\text { siswa }\end{array}$ & $\begin{array}{c}\text { Persentase } \\
(\%)\end{array}$ \\
\hline 1. & $\begin{array}{l}\text { Bertanggungjawab } \\
\text { terhadap tugas yang } \\
\text { diberikan }\end{array}$ & 17 orang & $85 \%$ \\
\hline 2. & $\begin{array}{l}\text { Kerjasama antar teman } \\
\text { kelompok terjalin dengan } \\
\text { baik }\end{array}$ & 18 orang & $90 \%$ \\
\hline 3. & $\begin{array}{l}\text { Siswa lebih aktif dan } \\
\text { percaya diri bertanya } \\
\text { kepada guru mengenai } \\
\text { kesulitan yang dihadapi }\end{array}$ & 17 orang & $85 \%$ \\
\hline 4. & $\begin{array}{l}\text { Keseriusan siswa dalam } \\
\text { menjiwai tarian }\end{array}$ & 18 orang & $90 \%$ \\
\hline
\end{tabular}

Sumber data: Pengolahan data hasil observasi aktivitas belajar seni tari siswa siklus 2

\section{Refleksi}

Pada siklus ke dua ini peningkatan aktivitas, keaktifan, tanggungjawab dan kerjasama siswa lebih meningkat. Rasa percaya diri siswa lebih baik dari sebelumnya. Pelaksanaan tindakan di kelas dengan menggunakan metode pembelajaran jigsaw menghasilkan peningkatan prestasi belajar yang memuaskan di dalam kelas. Hal ini dapat dilihat dari nilai belajar siswa yang dapat memahami materi yang diberikan oleh guru. Dengan demikian metode pembelajaran jigsaw berpengaruh pada peningkatan prestasi belajar siswa.

\section{Pembahasan}

Pada akhir siklus I pertemuan terakhir, dilakukan pengambilan data pemahaman siswa terhadap materi yang telah diberikan dengan cara postest. Nilai ketuntasan siswa dalam belajar seni tari adalah 75. Dari 20 siswa kelas X IPS1 yang dinyatakan lulus atau telah memenuhi syarat ketuntasan belajar sejumlah 12 siswa atau sebesar $60 \%$. Sedangkan jumlah siswa yang belum tuntas sejumlah 8 siswa atau sebesar $40 \%$.

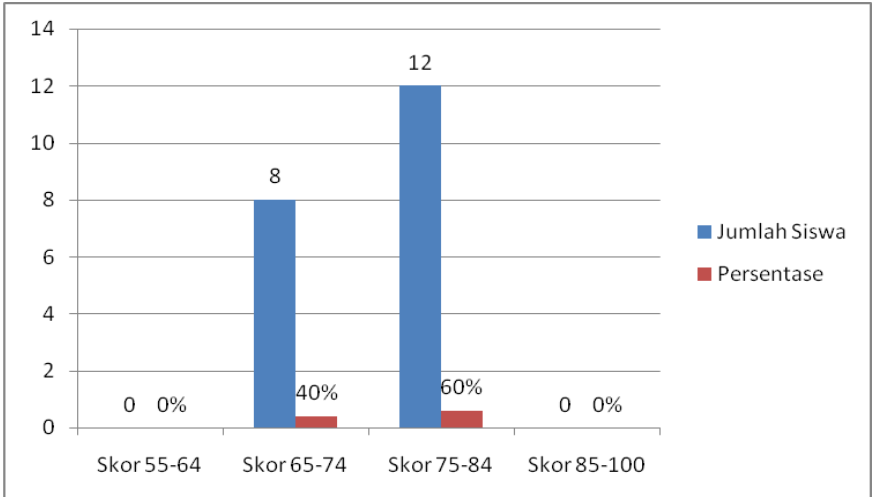

Gambar 1. grafik Persentase Nilai Seni Tari Siswa Siklus I

Perolehan nilai dikelompokkan menjadi empat kelompok rentang nilai. Empat rentang nilai tersebut adalah 55-64, 65-74, 75-84, 85-100. Banyaknya siswa yang memperoleh nilai 55 sampai 64 tidak ada. Siswa yang memperoleh nilai 65 sampai dengan 74 sebanyak 8 siswa atau $40 \%$. Siswa yang mendapatkan nilai 75 sampai dengan 84 sebanyak 12 siswa atau $60 \%$. Sedang siswa yang mendapatkan nilai 85 samapi 100 tidak ada. Nilai rata-rata ketuntasan secara klasikal yang dicapai baru mencapai 74 .

Berdasarkan hasil pengamatan kegiatan belajar siswa Peningkatan juga dapat dilihat dari aktivitas siswa yang lebih baik dari pada sebelumnya. Siswa lebih bertanggungjawab terhadap tugas yang diberikan, kerjasama antar teman kelompok terjalin dengan baik. Siswa lebih aktif dan percaya diri bertanya kepada guru mengenai kesulitan yang dihadapinya.

Pada siklus II ini peningkatan aktivitas, keaktifan, tanggungjawab dan kerjasama siswa lebih meningkat. Rasa percaya diri siswa lebih baik dari sebelumnya. Pelaksanaan tindakan di kelas dengan menggunakan metode pembelajaran jigsaw menghasilkan peningkatan prestasi belajar yang memuaskan di dalam kelas, hal ini tergambar dari perolehan prestasi belajar siswa

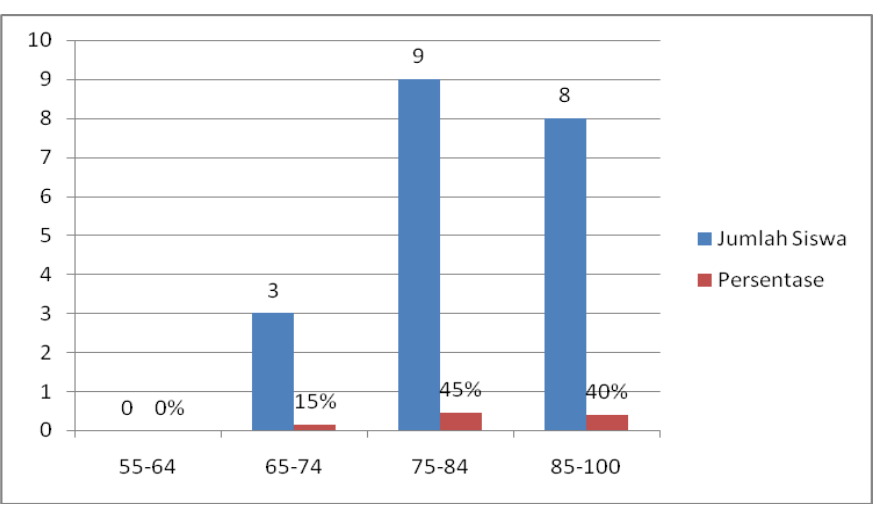

Gambar 2. Grafik Persentase Nilai Seni Tari Siswa Siklus II

Dari 20 siswa kelas X IPS 1 yang dinyatakan lulus atau telah memenuhi syarat ketuntasan belajar sejumlah 17 orang siswa atau sebesar $85 \%$. Sedangkan jumlah siswa yang belum tuntas sejumlah 3 siswa atau sebesar $15 \%$. 
Pada siklus II, hasil penerapan model pembelajaran Jigsaw secara berkelompok siswa yang memperoleh nilai 55 sampai 64 tidak ada. Siswa yang memperoleh nilai 65 sampai dengan 74 sebanyak 3 orang siswa atau $15 \%$. Siswa yang mendapatkan nilai 75 sampai dengan 84 sebanyak 9 orang siswa atau $45 \%$. Sedang siswa yang mendapatkan nilai 85 sampai 100 sebanyak 8 orang Siswa atau $40 \%$. Nilai rata-rata ketuntasan secara klasikal mencapai $85 \%$.

Dalam proses pembelajaran dengan menggunakan metode pembelajaran jigsaw ini, dapat mendorong siswa untuk saling berkerja sama dengan teman kelompok dan mempunyai rasa tanggungjawab akan tugasnya dalam kelompok, serta siswa lebih aktif dalam kegiatan belajar. Motivasi, aktivitas dan kreatifitas siswa yang tinggi dalam pembelajaran dengan materi tersebut dapat menciptakan hasil pembelajaran yang baik.

Hasil refleksi pada akhir siklus II, siswa yang semula masih memiliki kekurangan, pada tindakan tersebut siswa lebih aktif dan bisa mengikuti kegiatan pembelajaran dengan baik, meskipun masih ada 3 orang siswa yang belum mencapai KKM, namun secara klasikal keberhasilan prestasi belajar siswa sudah mencapai target $75 \%$ dari yang ditetapkan.

\section{SIMPULAN}

Penggunaan metode pembelajaran jigsaw dalam pembelajaran seni tari siswa kelas X IPS 1, dapat meningkatkan prestasi belajar. Serta aktivitas dan kreatifitas siswa meningkat dari sebelum diadakannya tindakan.

Dalam proses pembelajaran siswa lebih tertarik dan semangat belajar dengan materi yang diberikan oleh guru. Serta dengan metode jigsaw ini dapat meningkatkan rasa percaya diri, kerjasama dan tanggungjawab yang tinggi dengan kelompok.

Prestasi belajar siswa setelah adanya pembelajaran metode jigsaw yaitu sikulus I dari 20 siswa kelas X IPS1 yang dinyatakan lulus atau telah memenuhi syarat ketuntasan belajar sejumlah 12 siswa atau sebesar $60 \%$. Sedangkan jumlah siswa yang belum tuntas sejumlah 8 siswa atau sebesar $40 \%$.

Pada Siklus II meningkat dari 20 siswa kelas $\mathrm{X}$ IPS 1 yang dinyatakan lulus atau telah memenuhi syarat ketuntasan belajar sejumlah 17 orang siswa atau sebesar $85 \%$. Sedangkan jumlah siswa yang belum tuntas sejumlah 3 siswa atau sebesar $15 \%$.

Dalam hal ini Guru hendaknya bervariasi dalam penggunaan metode pembelajaran sehingga ketika menyampaikan materi siswa lebih termotivasi dan tidak merasa jenuh serta dapat dengan mudah menerima dan memahami materi yang disampaikan. Oleh karena itu disarankan kepada guru untuk dapat menerapkan metode jigsaw dalam pembelajaran Seni Budaya.

\section{DAFTAR PUSTAKA}

Anni, Chatarina tri, dkk. 2006. Psikologi Belajar. Semarang: Universitas Negeri Semarang.

Isjoni. 2013. Cooperative Learning. Bandung: Alfabeta.

Soedarsono, dkk. 1996. Indonesia Indah "Tari Tradisional Indonesia". Jakarta: Yayasan Harapan Kita/BP 3 TMII.

Suyadi. 2010. Panduan Penelitian Tindakan Kelas. Yogyakarta: Diva Press. Tim Pengembangan

Trianto. 2009. Mendesain Model Pembelajarn InovatifProgresif. Jakarta: Kencana Prenada Media Group.

Tim Pengembangan Ilmu Pendidikan .2007.Ilmu dan Aplikasi Pendidikan. Bandung: IMTIMA

Yoni, Acep. 2010. Menyusun Penelitian Tindakan Kelas. Yogyakarta: Family 